\begin{tabular}{cc}
\hline & International Journal of Engineering \& Technology, $7(3.27)(2018) 41-46$ \\
SPC & International Journal of Engineering \& Technology \\
\hline
\end{tabular}

\title{
Mathematical Modeling of Battery and Ultra Capacitor for Photo Voltaic System
}

\author{
Rupanshu Suhane $^{1 *}$, M.K. Chopra ${ }^{2}$, V.K. Sethi ${ }^{3}$ \\ ${ }^{1}$ Ph.D. Research Scholar, RKDF IST, SRK University, Bhopal, M.P. \\ ${ }^{2}$ HOD, Department of Mechanical, RKDFIST, SRK University, Bhopal, M.P. \\ ${ }^{3}$ V.C. RKDF University, Bhopal, M.P. \\ *Corresponding author E-mail:rupanshu18@gmail.com
}

\begin{abstract}
In this paper the scientific displaying of battery and ultra capacitor is performed for solar photovoltaic system. The expansion of the ultra capacitor bank displays the requirement for a philosophy to upgrade the photovoltaic system to avoid abundance battery stockpiling. This work traces the strategy used to streamline the blend of photovoltaic boards, batteries, and ultra capacitors for a given solar radiation and load profile. Lessening supplies of petroleum derivative, top oil and the natural effect of non-renewable energy sources on the earth has energized a development in manageable energies, for example, wind and solar power.
\end{abstract}

Keywords: State of charge (SOC), Ultra Capacitor (UC), Photovoltaic (PV), Hybrid Energy Storage System (HESS).

\section{Introduction}

This work falls under the vitality Storage Consortium activity in Sustainable Power Generation and Supply. The key inspiration for this examination is that conveyed wind control system and, specifically little scale remote-territory wind control system, can give an in fact practical choice to future remote vitality necessities. Worries about the earth, maintainability and expanding vitality costs have made a prerequisite to investigate elective, more reasonable methods for vitality age, for example, wind control. Independent photovoltaic boards are irregular supportable vitality sources which require vitality stockpiling to adjust age and request, as photovoltaic age is time and climate subordinate. Customarily batteries are the most widely recognized capacity innovation for photovoltaic system. Photovoltaic batteries can experience expanded times of low State of Charge (SOC), bringing about sulphation and stratification, decreasing battery lifetime. Independent photovoltaic system are regularly utilized as a part of remote zones from the national lattice for water system system, requiring dc engine beginning bringing about high inrush ebb and flow, cathodic security system for oil and gas pipelines, crisis telephones, cautioning signs, and media transmission repeater stations, bringing about heartbeat releasing of the battery. A blend of drained battery SOC and high burst current can bring about untimely loss of load because of stringent battery Low Voltage Disconnect (LVD) limits actualized by the battery administration system . A mix of Valve Regulated Lead Acid (VRLA) batteries and ultra capacitors in a Hybrid Energy Storage System (HESS), which builds the power thickness of the general system, is analyzed. Working the ultra capacitor bank under high power conditions diminishes the strain of substantial current extraction from the battery bank.

\section{Battery for Energy Storage Systems}

Selection of appropriate battery for cross breed vitality stockpiling system supporting sun oriented PV application relies upon a few variables. As a rule rehearse, the vitality yield of Solar PV system is put away in a battery or a battery bank. Batteries are for the most part utilized as a part of the remain solitary system to expand the system unwavering quality. The principle elements of the battery in a PV system are: (a) to store electrical vitality produced by the PV cluster and to supply vitality to electrical loads as expected; (b) to give adjustment to the PV system by providing capacity to electrical burdens at stable voltages and streams, by smothering homeless people that may happen because of providing nonlinear loads. (c) to supply surge currents to the electrical loads under dynamic operation. (Zakeri, et al.(2015); Sauer, et al.(2001); Xu, et al.(2013))

\subsection{Battery Types}

A solar PV for the most part utilizes lead-corrosive batteries as vitality stockpiling segment due to their minimal effort; great execution attributes and simplicity of accessibility. NickelCadmium cells are utilized for low temperature applications, yet their high introductory cost makes their utilization uneconomical. The determination of the reasonable battery relies on the application.

\subsubsection{Battery Charging}

In a stand-alone PV system, the battery charging comprises of three modes; (1) typical or mass charge, (2) completing or skim charge and (3) balancing charge.

Bulk or Normal Charge: It is the underlying bit of a charging cycle performed at any charge rate and it happens between $80 \%$ and $90 \%$ condition of charge (SOC). 
Float or Finishing Charge: In this method of charging the charge rate is low or medium. At the point when the battery is completely charged, the majority of the dynamic material in the battery is changed over to its unique frame, by and large voltage/current direction are required to restrict the cheat provided to the battery. Equalizing Charge: It comprises of a present constrained charge to higher voltage limits than set for the completing or buoy charge. It is done intermittently to keep up consistency among singular cells.

\subsubsection{Battery Discharging}

Depth of Discharge (DOD The battery DOD is characterized as the level of battery pulled back limit contrasted with the aggregate limit when the battery is completely charged. The two common qualifiers for depth of discharge in PV systems are the allowable or maximum DOD and the average daily DOD and are described as follows:

State of Charge (SOC): The state of charge (SOC) is characterized as the measure of vitality as a level of the vitality put away in a completely charged battery.

Self-Discharge Rate In open-circuit mode with no charge or release current, a battery experiences a decrease in condition of charge, because of inward components and misfortunes inside the battery.

Battery Life time Battery lifetime is needy upon various plan and operational variables, including the parts and materials of battery development, temperature, recurrence, profundity of releases, and normal condition of charge and charging techniques.

\subsection{Battery Equivalent Circuit}

The battery proportional circuit display helps in getting an unmistakable understanding with respect to cells reaction to various conditions, which are required for sunlight based PV application outline.

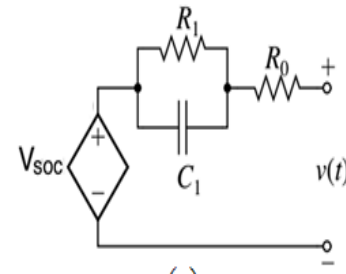

(a)

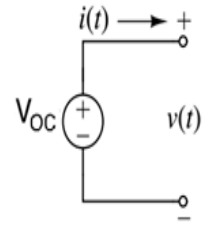

(b)

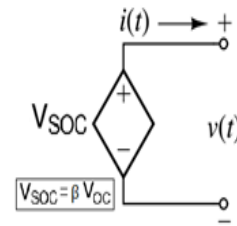

(c)
Fig. 1: Battery equivalent circuit

\section{Open-Circuit Voltage and State of Charge}

The battery proportionate electrical circuit of figure 1(a) is inferred by starting with the least difficult model as a perfect voltage source figure 1(b). The terminal voltage in the battery model of figure 1(b), isn't an element of present or past use, and voltage is basically consistent. From useful perspective this model experiences insufficiency.

\subsection{State of Charge}

In practice, the open-circuit voltage of a completely charged battery cell is higher than when it is released. This state of reliance of open circuit battery voltage $\mathrm{V}_{\mathrm{OC}}$ on charge status of battery can be consolidated in the battery demonstrate appeared in figure 1(c) by presenting a needy voltage source $\mathrm{V}_{\mathrm{SOC}}=\beta \cdot \mathrm{V}_{\mathrm{OC}}$. The state of charge (SoC) factor $\beta$, of a cell is defined as $\beta=100 \%$ when the cell is fully charged and $\beta=0 \%$ when the cell is fully discharged.Qis measured in Ah or mAh. SOC can be modelled as $\dot{\beta}($ where $\dot{\beta}=\mathrm{d} \beta / \mathrm{dt})$

$\dot{\beta}(\mathrm{t})=\frac{-\mathrm{i}(\mathrm{t})}{\mathrm{Q}}$
$\beta(t)=\beta\left(t_{0}\right)-\frac{1}{Q} \int_{t_{0}}^{t} i(\tau) d \tau$

where $\mathrm{i}(\mathrm{t})$ has positive sign on discharge.

In discrete time where, $\mathrm{n}$ is the number of samples, with current assumed constant over sampling interval $\Delta t$, we have

$\beta[\mathrm{n}+1]=\beta[\mathrm{n}]-\mathrm{i}[\mathrm{n}] \cdot \frac{\Delta \mathrm{t}}{\mathrm{Q}}$

the charge (or Coulomb) efficiency of the cells depends on various stray factors that makes the cell inefficient. In order to accommodate such factors a charge efficiency factor $\eta(t)$ is included in the above equation,

$\dot{\beta}(\mathrm{t})=\frac{-\mathrm{i}(\mathrm{t})}{\mathrm{Q}} \cdot \eta(\mathrm{t})$

$\beta[\mathrm{n}+1]=\beta[\mathrm{n}]-\mathrm{i}[\mathrm{n}] \cdot \eta[\mathrm{n}] \cdot \frac{\Delta \mathrm{t}}{\mathrm{Q}}$

where, Coulomb efficiency is the ratio of charge out from battery to the charge in into the battery. $\eta(n) \leq 1$ when the cell is on charge and $\eta(n)=1$ when cell is on discharge.

The battery open circuit terminal voltage $\mathrm{V}_{\mathrm{OC}}$ also depends on the electrolyte temperature whose effect is included in the model as $\mathrm{V}_{\mathrm{OC}}(\beta(\mathrm{t}), \mathrm{T}(\mathrm{t}))$.

DOD $=1-$ SOC

DOD, when expressed in Ah:

$\mathrm{DOD}=\mathrm{Q}(1-\mathrm{SOC})$

Equivalent series resistance

When the load is applied to a battery, it is observed that the cell's voltage drops. This effect of load on cell voltage can be realized by introducing a resistance $\mathrm{R} 0$ in series with the ideal voltage source as shown in figure 2(a) and expressed by the following voltage equation,

$v(t)=V_{\text {SOC }}-i(t) \cdot R_{0}$

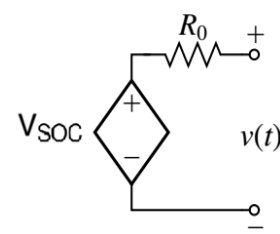

(a)

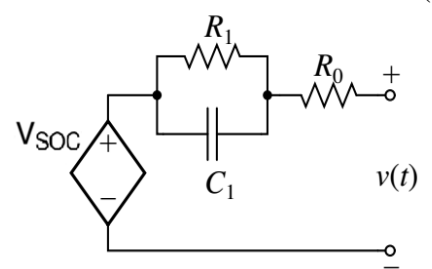

(b)
Fig. 2: Battery equivalent circuit incorporating (a) battery loss (b) diffusion voltages

The energy is dissipated in the resistor $\mathrm{R}_{0}$ as heat, and therefore the energy efficiency of the battery cell has imperfection associated with it.

\subsection{Diffusion Voltages}

The battery terminal voltage encounters a lessening in its open circuit esteem while being stacked; this decrease is alluded to as polarization. Thei $(\mathrm{t}) \times \mathrm{R}_{0}$ is a case of polarization, demonstrating a prompt reaction to an adjustment in input current.

A non-prompt, powerful reaction is likewise seen to a stage change in current. At the point when the cell is permitted to rest, its voltage does not promptly come back to $\mathrm{V}_{\mathrm{OC}}$, but rather rots gradually (setting aside significant opportunity to achieve $\mathrm{V}_{\mathrm{OC}}$ ) as appeared in figure 3 . 


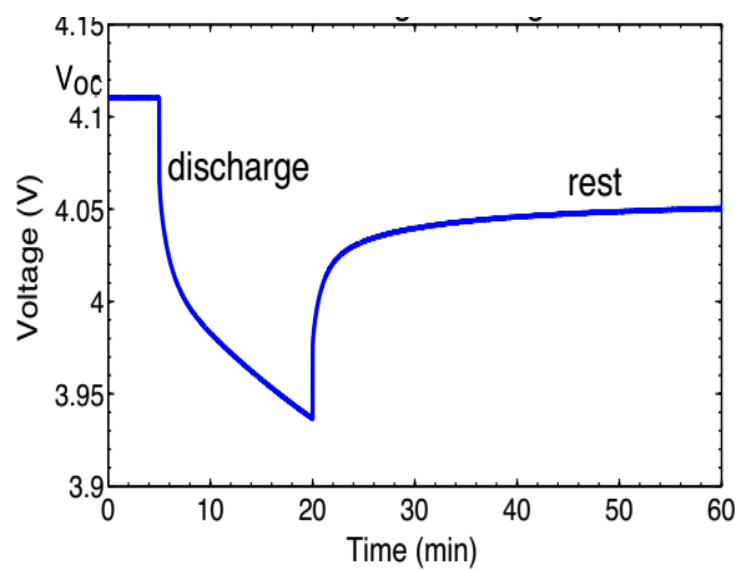

Fig. 3: Polarization during discharge and rest

This phenomenon is due to slow diffusion processes in the cell, and hence this slowly-changing voltage is referred to as diffusion voltage. Its effect can be realized by incorporating one or more parallel resistor-capacitor sub-circuits into the equivalent circuit as shown in Figure 3. The cell voltage is modelled as:

$\mathrm{v}(\mathrm{t})=\mathrm{V}_{\mathrm{SOC}}-\mathrm{v}_{\mathrm{C}_{1}}(\mathrm{t})-\mathrm{i}(\mathrm{t}) \cdot \mathrm{R}_{0}$

The above equation can be re-written in terms of element currents as follows

$v(t)=V_{\text {SOC }}-R_{1} i_{R_{1}}(t)-R_{0} \cdot i(t)$

Also $i(t)=i_{R_{1}}(t)+i_{C_{1}}(t)=i_{R_{1}}(t)+C_{1} \frac{d v_{C_{1}}(t)}{d t}$

$i(t)=i_{R_{1}}(t)+R_{1} C_{1} \frac{d i_{R_{1}}(t)}{d t}$

$\frac{\mathrm{di}_{\mathrm{R}_{1}}(\mathrm{t})}{\mathrm{dt}}=-\frac{1}{\mathrm{R}_{1} \mathrm{C}_{1}} \mathrm{i}_{\mathrm{R}_{1}}(\mathrm{t})+\frac{1}{\mathrm{R}_{1} \mathrm{C}_{1}} \mathrm{i}(\mathrm{t})$

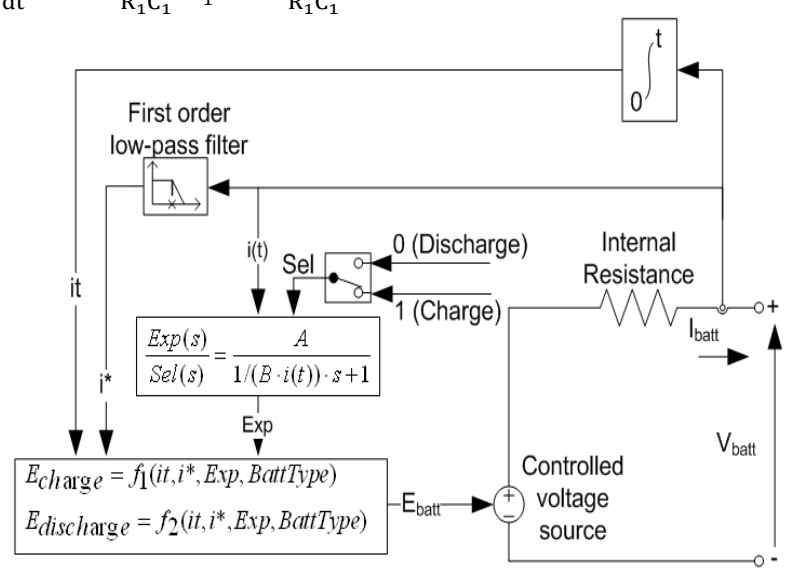

Fig. 4: Lead Acid Battery Simulink Model

Figure 4 represents the Simulink model of a lead acid battery. Discharge $\operatorname{Model}\left(\mathrm{i}^{*}>0\right)$

$\mathrm{f}_{1}\left(\mathrm{it}, \mathrm{i}^{*}, \mathrm{i}, \operatorname{Exp}\right)=\mathrm{E}_{0}-\mathrm{K} \cdot \frac{\mathrm{Q}}{\mathrm{Q}-\mathrm{it}} \cdot \mathrm{i}^{*}-\mathrm{K} \cdot \frac{\mathrm{Q}}{\mathrm{Q}-\mathrm{it}} \cdot \mathrm{it}+\mathcal{L}^{-1}\left(\frac{\operatorname{Exp}(\mathrm{s})}{\operatorname{Sel}(\mathrm{s})} \cdot 0\right)$

Discharge $\operatorname{Model}\left(\mathrm{i}^{*}<0\right)$

$\mathrm{f}_{1}\left(\mathrm{it}, \mathrm{i}^{*}, \mathrm{i}, \operatorname{Exp}\right)=\mathrm{E}_{0}-\mathrm{K} \cdot \frac{\mathrm{Q}}{\mathrm{it}+0.1 \cdot \mathrm{Q}} \cdot \mathrm{i}^{*}-\mathrm{K} \cdot \frac{\mathrm{Q}}{\mathrm{Q}-\mathrm{it}} \cdot \mathrm{it}+\mathcal{L}^{-1}\left(\frac{\operatorname{Exp}(\mathrm{s})}{\operatorname{Sel}(\mathrm{s})} \cdot\right.$

$\left.\frac{1}{\mathrm{~s}}\right)(14)$

Where,

$\mathrm{E}_{\text {Batt }}=$ Nonlinear voltage $(\mathrm{V})$

$\mathrm{E}_{0}=$ Constant voltage $(\mathrm{V})$
$\operatorname{Exp}(\mathrm{s})=$ Exponential zone dynamics $(\mathrm{V})$

$\operatorname{Sel}(\mathrm{s})=$ Represents the battery mode .

$\operatorname{Sel}(s)=0$ during battery discharge,

$\operatorname{Sel}(\mathrm{s})=1$ during battery charging.

$\mathrm{K}=$ Polarization constant $(\mathrm{Ah}-1)$ or Polarization resistance (Ohms)

$\mathrm{i}^{*}=$ Low frequency current dynamics $(\mathrm{A})$

$\mathrm{i}=$ Battery current $(\mathrm{A})$

it $=$ Extracted capacity $(\mathrm{Ah})$

$\mathrm{Q}=$ Maximum battery capacity $(\mathrm{Ah})$

$\mathrm{A}=$ Exponential voltage $(\mathrm{V})$

$\mathrm{B}=$ Exponential capacity $(\mathrm{Ah})-1$

\section{Ultra-Capacitor System Modeling and Design}

Ultra-Capacitors don't have any dielectrics and it works using the idea of electric twofold layer. Ultra-capacitor is called an electrochemical gadget however there are no synthetic responses engaged with its vitality stockpiling system rather it stores vitality electro statically by polarizing an electrolytic arrangement introduce between its terminals appeared in the fig. 4.9 This component is exceedingly reversible, enabling the ultra-capacitor to charge and release to as vast as a large number of times. A ultra-capacitor can be seen as two nonreactive permeable plates kept inside an electrolyte with a connected voltage over the plates. The connected potential on the positive plate draws in the negative particles in the electrolyte, while the potential on the negative plate pulls in the positive particles. This adequately makes two layers of capacitive stockpiling, one where the charges are isolated at the positive plate, and another at the negative plate. A ultracapacitor gets its zone from a permeable carbon-based cathode material. Ultra-capacitors comprise of a positive anode, a negative terminal, a separator between these two cathodes, and an electrolyte filling the porosities of the two cathodes and separator. Figure 5 shows the Ultra-capacitor arrangement and various materials employed for various parts with approximate dimensions. Table 1 summarises the material employed for construction of UC.(Kotz, et al.(1999); Schneuwly, (2005); Shah, et al.(2008))

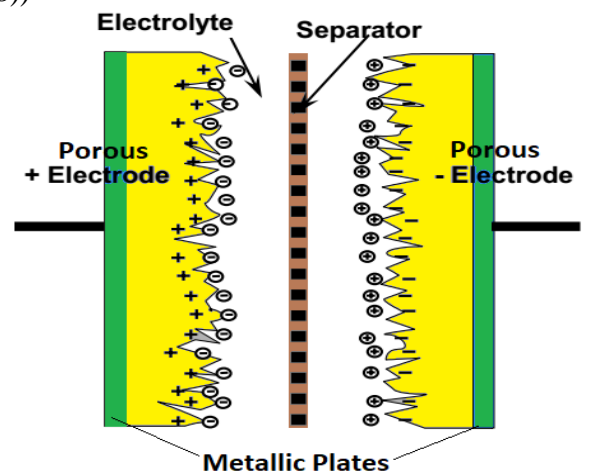




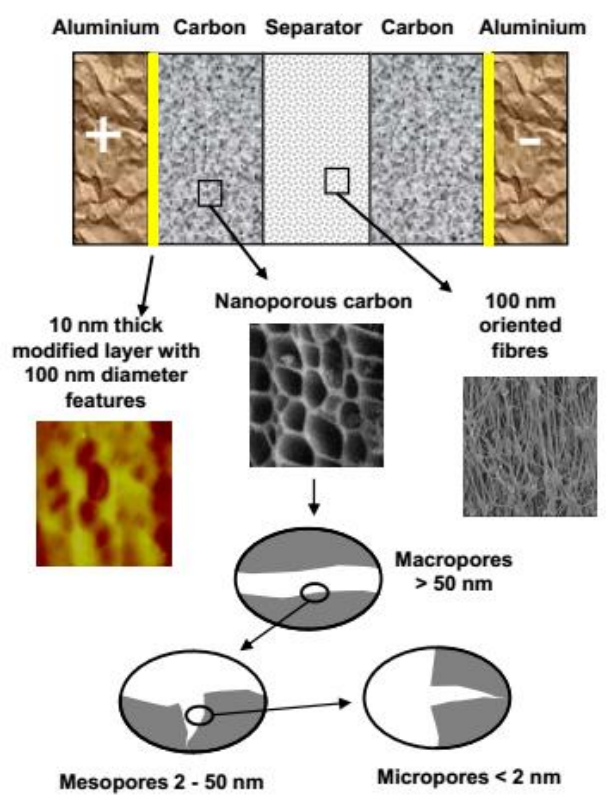

Fig. 5: Internal construction of ultra-capacitor

Table 1: Materials Used for Construction of Ultra-Capacitor

\begin{tabular}{|l|l|}
\hline UC Parts & Material used \\
\hline Electrodes: & Activated Carbon \\
\hline Separator: & Polypropylene or Cellulose \\
\hline Electrolyte: & Quaternary salt ; Organic solvent (acetonitrile) \\
\hline Outer plates: & Aluminium or Steel \\
\hline
\end{tabular}

\subsection{Equivalent Circuit}

The equivalent circuit of an ultra-capacitor contains four perfect parts as appeared in figure 6. The arrangement opposition Rs which is additionally alluded to as the identical arrangement obstruction (ESR). This is the principle supporter of intensity misfortune amid charging and releasing of the capacitor. A parallel obstruction $\mathrm{Rp}$ represents the self-release of $\mathrm{UC}$, a capacitance $\mathrm{C}$ and an arrangement inductor $\mathrm{L}$ that is typically little because of the phone development.

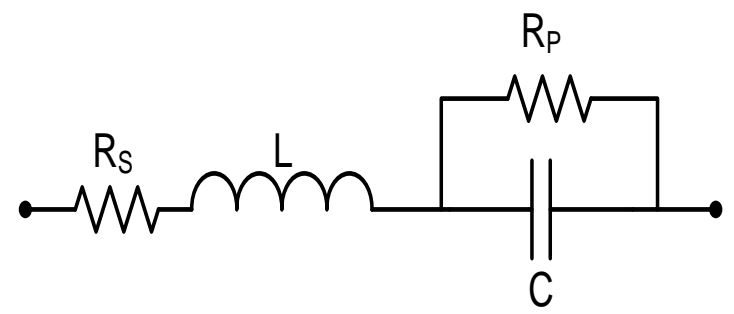

Fig. 6: First order equivalent circuit of ultra-capacitor

Since Rp is always much larger than Rs it can be ignored. Ultracapacitor internal resistance is far less as compared with the storage batteries and as a consequence capacitors are more efficient owing to less internal loss, provided current flow should not be excessive.

\subsubsection{Capacitor Fundamental Equations}

When an electric potential is applied to the capacitor, an electrical field develops between two electrically charged electrode-plates. The applied potential difference, $\mathrm{V}$ is directly proportional to the distance between the plates $d$ and to the electric field strength $\mathrm{E}$, through the relationship:

$$
\mathrm{V}=\mathrm{E} \cdot \mathrm{d}
$$

The ratio of charge $\mathrm{Q}$ to the potential difference defines the capacitance of the capacitor:
$\mathrm{C}=\frac{\mathrm{Q}}{\mathrm{V}}$

Differentiating equation (4.16) with respect to time gives

$\frac{\mathrm{dV}}{\mathrm{dt}}=\frac{1}{\mathrm{C}} \cdot \frac{\mathrm{dQ}}{\mathrm{dt}}=\frac{1}{\mathrm{C}} . \mathrm{I}$

From equation 17 it is evident that with a constant current, I, the voltage will rise linearly with a slope equal to the inverse of the capacitance. For higher operating voltage requirements, capacitors can be connected in series. as shown in figure 7 .

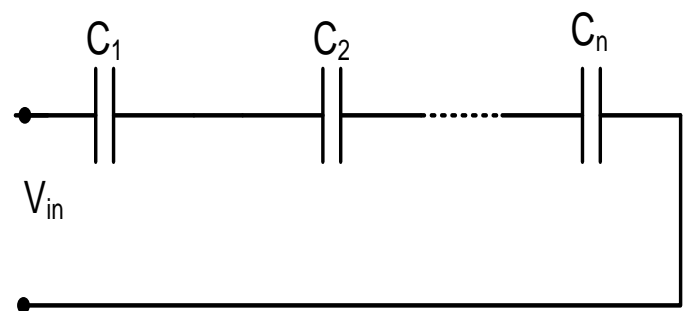

Fig. 7: Capacitors connected in series.

$\mathrm{V}_{\text {module }}=\mathrm{V}_{1}+\mathrm{V}_{2}+\cdots+\mathrm{V}_{\mathrm{n}}=\mathrm{Q}\left(\frac{1}{\mathrm{C}_{1}}+\frac{1}{\mathrm{C}_{2}}+\cdots \frac{1}{\mathrm{C}_{\mathrm{n}}}\right)$

$\frac{1}{\mathrm{C}_{\mathrm{eq}}}=\left(\frac{1}{\mathrm{C}_{1}}+\frac{1}{\mathrm{C}_{2}}+\cdots \frac{1}{\mathrm{C}_{\mathrm{n}}}\right)$

$\mathrm{C}_{\mathrm{eq}}=\frac{1}{\frac{1}{\mathrm{C}_{1}}+\frac{1}{\mathrm{C}_{2}}+\cdots+\frac{1}{\mathrm{C}_{\mathrm{n}}}}$

The state of charge (SoC) becomes equal for all capacitors connected in series, independent of their capacitances: $Q_{1}=Q_{2}=$ $\mathrm{Q}_{\mathrm{n}}$. In a series connected capacitor bank, the mismatch between the internal resistances results in the non-uniform distribution of voltage across the capacitors. When identical capacitors are combined then the equivalent capacitance becomes:

$\mathrm{C}_{\mathrm{eq}}=\mathrm{C}_{\text {cell }} \times \frac{\text { number of capacitors in parallel }}{\text { number of capacitors in series }}$

Where,

$\mathrm{C}_{\text {eq }}=$ equivalent capacitance of the bank

$\mathrm{C}_{\text {cell }}=$ individual cell voltage.

If a higher capacitance is needed, capacitors are connected in parallel as shown in figure 8 .

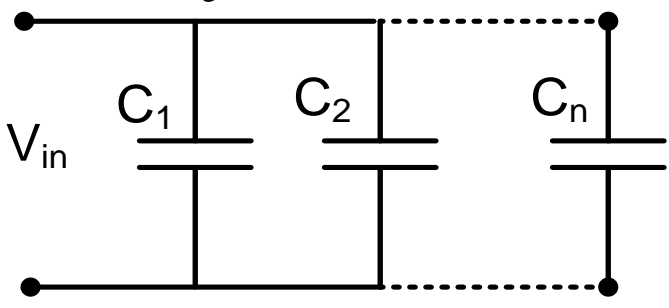

Fig. 8: Capacitors connected in parallel

$\mathrm{Q}_{\text {total }}=\mathrm{Q}_{1}+\mathrm{Q}_{2}+\cdots+\mathrm{Q}_{\mathrm{n}}$

$\mathrm{C}=\mathrm{Q}_{\text {total }} \cdot \mathrm{V}=\left(\mathrm{Q}_{1}+\mathrm{Q}_{2}+\cdots+\mathrm{Q}_{\mathrm{n}}\right) \cdot \mathrm{V}$ Coulomb

The total capacitance becomes the sum of the capacitances of the individual capacitors

$\mathrm{C}_{\mathrm{eq}}=\mathrm{C}_{1}+\mathrm{C}_{2}+\cdots+\mathrm{C}_{\mathrm{n}}=\mathrm{Q}_{\text {total }} \cdot \mathrm{V}$ Farad

In general, the potential energy stored in the electric field is given by $[15$ 


$$
\mathrm{W}=\frac{1}{2} \mathrm{CV}^{2} \text { Joules }
$$

When the capacitor is discharged, the voltage drops from the initial voltage $V_{1}$ to the voltage $V_{2}$, and in the process it releases some of the stored potential energy as per the following equation

$\Delta \mathrm{W}=\frac{1}{2} \mathrm{C}\left(\mathrm{V}_{2}-\mathrm{V}_{1}\right)^{2}$

The state of charge of the ultra-capacitor, $\mathrm{SoC}_{\mathrm{UC}}$, is defined as the ratio between the remaining energy and the maximum stored energy of the ultra-capacitor. Using $\mathrm{W}=1 / 2 . \mathrm{CV}^{2}$, the state of charge expressed in terms of terminal voltage becomes:

$\mathrm{SoC}_{\mathrm{UC}}=\frac{\mathrm{W}}{\mathrm{W}_{\max }}=\frac{\mathrm{V}^{2}}{\mathrm{~V}_{\max }^{2}} \cdot 100 \%$

Where,Vis the terminal voltage of the ultra-capacitor and $V_{\text {max }}$ is equivalentto the rated voltage of the ultra-capacitor. The ultracapacitors effective power density is defined as the instantaneous powerdelivered at rated voltage $V_{\text {rated }}$ with internal resistance, ESR, specified at $1 \mathrm{kHz}$ frequency:

$\mathrm{P}_{\max }=\frac{\left(\mathrm{V}_{\text {rated }}\right)^{2}}{4 \cdot \mathrm{ESR}_{1 \mathrm{kHz}} \cdot \mathrm{mass}} \quad \mathrm{kg}$

$\mathrm{ESR}=$ Equivalent Series Resistance

The capacitance varies directly with the area $\mathrm{A}$ of the parallel plates and inversely with the distance between the plates.

$\mathrm{C}=\frac{\epsilon_{0} \epsilon_{\mathrm{r}} \cdot \mathrm{A}}{\mathrm{d}} \quad$ Farad

where $\epsilon_{0}$ is the permittivity constant of vacuum and $\epsilon_{\mathrm{r}}$ is the relative dielectric constant of an eventual insulating dielectric between the plates.

Calculation of charge/discharge time

It is to be ensured that the charging voltage does not exceed its rated voltage. The time required for the constant current and constant resistance charging/discharging are represented by equations (28) and (29) below:

Constant current discharge

$\mathrm{t}=\mathrm{C} \times \frac{\mathrm{v}_{0}-\mathrm{v}_{1}}{\mathrm{I}}$

Constant resistance discharge

$\mathrm{t}=\mathrm{C} \times \mathrm{R} \times \ln \left(\frac{\mathrm{V}_{1}}{\mathrm{~V}_{0}}\right)$

Where, $\mathrm{t}=$ charge/discharge time $(\mathrm{s}), \mathrm{V}_{0}=$ initial voltage $(\mathrm{V}), \mathrm{V}_{1}=$ final voltage after $\mathrm{t}(\mathrm{s})(\mathrm{V}), \mathrm{I}=\mathrm{constant}$ current load (A) and $\mathrm{R}=$ constant resistive load $(\Omega)$.

The above equation, including internal resistance drop becomes.

$\mathrm{t}=\frac{\left[\mathrm{C} \times\left(\mathrm{V}_{0}-\mathrm{V}_{1}\right)-(\mathrm{I} \times \mathrm{ESR})\right]}{\mathrm{I}}$

\subsection{Ultra-Capacitor Modelling}

Figure 9 shows the mathematical realization of the UltraCapacitor model.

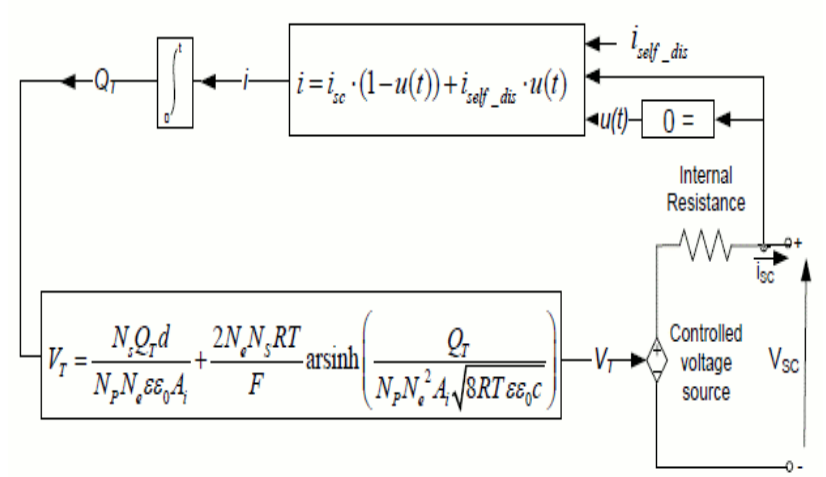

Fig. 9: Ultra Capacitor Simulink Model

The UC output voltage is expressed using equation as:

$V_{S C}=\frac{N_{s} Q_{T} d}{N_{p} N_{e} \varepsilon_{r} \varepsilon_{0} A_{i}}+\frac{2 N_{e} N_{S} R T}{F} \sinh ^{-1}\left(\frac{Q_{T}}{N_{p} N_{e}^{2} A_{i} \sqrt{8 R T \varepsilon_{r} \varepsilon_{0} c}}\right)-R_{S C} \cdot i_{S C}$ (31)

$\mathrm{Q}_{\mathrm{T}}=\int \mathrm{i}_{\mathrm{SC}} \cdot \mathrm{dt}$

To represent the self-discharge phenomenon, the UC electric charge is modified as follows (when $\mathrm{i}_{\mathrm{SC}}=0$ ):

$\mathrm{Q}_{\mathrm{T}}=\int \mathrm{i}_{\mathrm{self} \text { discharge }} \cdot \mathrm{dt}$

Where, $i_{\text {self discharge }}=\left\{\begin{array}{cc}\frac{\mathrm{C}_{\mathrm{T}} \cdot \alpha_{1}}{1+\mathrm{sR}_{\mathrm{SC}} \mathrm{C}_{\mathrm{T}}} & \text { if } \mathrm{t}-\mathrm{t}_{\mathrm{oc}} \leq \mathrm{t}_{3} \\ \frac{\mathrm{C}_{\mathrm{T}} \cdot \alpha_{2}}{1+\mathrm{sR} \mathrm{R}_{\mathrm{SC}} \mathrm{C}_{\mathrm{T}}} & \text { if } \mathrm{t}_{3}<t-\mathrm{t}_{\mathrm{oc}} \leq \mathrm{t}_{4} \\ \frac{\mathrm{C}_{\mathrm{T}} \cdot \alpha_{3}}{1+\mathrm{sR} \mathrm{SC}_{\mathrm{S}} \mathrm{C}_{\mathrm{T}}} & \text { if } \mathrm{t}-\mathrm{t}_{\mathrm{oc}}>\mathrm{t}_{4}\end{array}\right\}$

The constants $\alpha_{1}, \alpha_{2}$, and $\alpha_{3}$ are the rates of change of the UC voltage during time intervals (toc, $\mathrm{t} 3),(\mathrm{t} 3, \mathrm{t} 4)$, and $(\mathrm{t} 4, \mathrm{t} 5)$ respectively, as shown in the figure 10 :

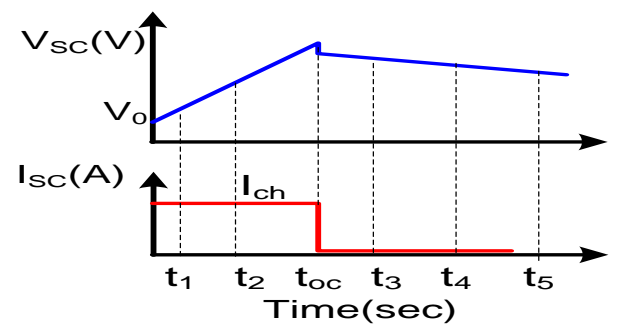

Fig. 10: Ultra Capacitor VSC and ISC plot against time

Table 2: Description of UC Variables

\begin{tabular}{|c|l|}
\hline Variable & Description \\
\hline $\mathrm{A}_{\mathrm{i}}$ & Interfacial area between electrodes and electrolyte $\left(\mathrm{m}^{2}\right)$ \\
\hline $\mathrm{C}$ & Molar concentration $\left(\mathrm{mol} / \mathrm{m}^{3}\right)$ equal toc $=\frac{1}{8 \mathrm{~N}_{\mathrm{A}} \mathrm{r}^{3}}$ \\
\hline $\mathrm{R}$ & Molecular radius $(\mathrm{m})$ \\
\hline $\mathrm{F}$ & Faraday constant \\
\hline $\mathrm{i}_{\mathrm{SC}}$ & UC Current $(\mathrm{A})$ \\
\hline $\mathrm{V}_{\mathrm{SC}}$ & UC Voltage $(\mathrm{V})$ \\
\hline $\mathrm{C}_{\mathrm{T}}$ & Total Capacitance $(\mathrm{F})$ \\
\hline $\mathrm{R}_{\mathrm{SC}}$ & Total resistance $($ ohms $)$ \\
\hline $\mathrm{N}_{\mathrm{e}}$ & Number of layers of electrodes \\
\hline $\mathrm{N}_{\mathrm{A}}$ & Avogadro constant \\
\hline $\mathrm{N}_{\mathrm{p}}$ & Number of parallel ultra-capacitors \\
\hline $\mathrm{N}_{\mathrm{S}}$ & Number of series ultra-capacitors \\
\hline $\mathrm{Q}_{\mathrm{T}}$ & Electric charge $(\mathrm{C})$ \\
\hline $\mathrm{R}$ & Ideal gas constant \\
\hline $\mathrm{D}$ & Molecular diameter \\
\hline $\mathrm{T}$ & Operating temperature $(\mathrm{K})$ \\
\hline$\varepsilon_{\mathrm{r}}$ & Permittivity of material \\
\hline$\varepsilon_{0}$ & Permittivity of free space \\
\hline
\end{tabular}

The SOC for a fully charged ultra-capacitor is $100 \%$ and for an empty ultra-capacitor is $0 \%$. The SOC is calculated as: 
$\mathrm{SOC}=\frac{\mathrm{Q}_{\text {initial }}-\int_{0}^{\mathrm{t}} \mathrm{i}(\tau) \mathrm{d} \tau}{\mathrm{Q}_{\mathrm{T}}} \times 100$

The accompanying suppositions are made for understanding the ultra-capacitor show. (a)Internal opposition is accepted consistent amid the charge and the release cycles; (b)The show does not consider temperature impact on the electrolyte material; (c) No maturing impact is considered; (d) Charge redistribution is the same for all estimations of voltage; (e) The square does not display cell adjusting; (f) Current through the ultra-capacitor is assumed to be continuous. (Oldham, (2008); Xu, N., et al.(2011))

\section{Conclusion}

This paper has introduced the plan, recreation, execution and investigation of a functioning half and half system comprising of battery and Ultra capacitor vitality stockpiling gadgets for sun based PV and wind-control applications. This work portrays the procedures used to build up a product stage fit for reproducing its execution over an agent period. This exploration work portrays the numerical displaying of battery in conjunction with ultra capacitor for cross breed vitality stockpiling system .

\section{References}

[1] Mohammadi M, Hosseinian SH \& Gharehpetian G.B "Optimization of hybrid solar energy sources/wind turbine systems integrated to utility grids as micro grid (MG) under pool/bilateral/hybrid electricity market using PSO", Solar Energy, Vol.86, No.1, (2012), pp.112-125.

[2] Heinrich Wilk OKA, "Utility connected photovoltaic systems", International Energy Agency (IEA): Solar Heating and Cooling Program, Contribution to design handbook, Expert meeting Monteux, (1992), pp.19-21.

[3] Ashari M, Keerthipala WL \& Nayar CV, "A Single Phase Parallel Y Connected Uninterruptible Power Supply and Demand Side Management System", IEEE Power Engineering Review, Vol.19, No.11, (1999).

[4] Ayvazyan GY, Kirakosyan GH \& Vardanyan AH, "Maximum Power Operation of PV system Using Fuzzy Logic Control", Armenian Journal of Physics, Vol.1, (2008), pp.155-159.

[5] Bouchafaa F, Beriber D \& Boucherit MS, "Modeling and simulation of a gird connected PV generation system with MPPT fuzzy logic control", IEEE 7th International Multi-Conference on Systems Signals and Devices (SSD), (2010), pp.1-7.

[6] Esram T \& Chapman PL, "Comparison of photovoltaic array maximum power point tracking techniques", IEEE Transactions on energy conversion, Vol.22, No.2, (2007), pp.439-449.

[7] Luo FL \& Jin L, "Two-quadrant DC/DC soft-switching converter", IEEE 31st Conference on Annual Power Electronics Specialists, Vol.1, (2000), pp.173-178.

[8] Gao Y \& Luo FL., "Theoretical Analysis on Performance of a 5V/12 V Push-pull Switched Capacitor DC /DC Converter", IEE International Conference IPEC, (2001).

[9] Hassaine L, LiasE O, Quintero J \& Haddadi M, "Digital power factor control and reactive power regulation for grid-connected photovoltaic inverter", Renewable Energy, Vol.34, No.1, (2009), pp.315-321.

[10] Salas V \& Olias E, "Over view of the state of technique for PV inverters used in low voltage grid-connected PV systems: inverters below 10kW", Renewable and Sustainable Energy Reviews, Vol.13, No.6-7, (2009), pp.1541-1550.

[11] Blaabjerg F, Chen Z \& Kjaer SB, "Power electronics as efficient inter face in dispersed power generation systems", IEEE Transact ions on Power Electronics, Vol. 19, No. 5, (2004), pp. 1184-1194,

[12] Wiechmann EP, Aqueveque $\mathrm{P}$, Burgos $\mathrm{R}$ \& Rodríguez J, "Efficiency of voltage source and current source inverters for highpower drives", IEEE Trans. Ind. Electron., Vol.55, No.4, (2008), pp.1771-1782

[13] B Kassimbekova, G Tulekova, V Korvyakov (2018). Problems of development of aesthetic culture at teenagers by means of the Kazakh decorative and applied arts. Opción, Año 33. 170-186
[14] Laxminarayana G \& Pradeep K, "Comparative Analysis of 3-,5and 7-level inverter using Space Vector PWM", International Journal of Advanced Research in Electrical, Electronics and Instrumentation Engineering, Vol.2, No.7, (2013), pp.3233-3241

[15] Rashid MH, Power Electronic Circuits, Devices and Applications. Third edition, (2006).

[16] Conway BE, Theory and Principles of Electrode Processes, Ronald, New York, (1965).

[17] Bode H, Lead-Acid Batteries, Wiley, New York, (1977)

[18] Kalhammer FR, "Advanced Batteries for Electric Vehicles: An Assessment of Performance and Availability of Batteries for Electric Vehicles", A Report of the Battery Technical Advisory Panel, prepared for the California Air Resource Board (CARB), (2000).

[19] Pasquier A, Plitz I, Menocaland S \& Amatucci G, "A comparative study of Li-ion battery, super capacitor and non aqueous asymmetric hybrid devices for automotive applications", Journal of Power Sources, Vol.115, (2003), pp.171-8.

[20] Syed FU, Kuang ML \& Ying H, "Derivation and Experimental Validation of a Power-Split Hybrid Electric Vehicle Model", IEEE Transactions on Vehicular Technology, Vol.55, No.6, (2006), pp.1731-1747.

[21] Fernandes LP \& Figueiredo JM, "Design and Implementation of an Efficient Hybrid System for Electricity Production", International Conference on Renewable Energies and Power Quality, (2008), pp.165-169.

[22] M Pallarès Piquer and O Chiva Bartoll (2017). La teoría de la educación desde la filosofía de Xavier Zubiri. Opción, Año 33, No. 82 (2017): 91-113 